\title{
Assessment of hydrological dynamics in the upper Okavango River Basins
}

\author{
Thomas Steudel, Hendrik Göhmann, Wolfgang-Albert Flügel \& Jörg Helmschrot
}

\begin{abstract}
The aim of this paper is to assess the hydrological system of the Okavango headwater tributaries, namely the Cuito and Cubango subcatchments, and the flow characteristics of the Okavango after their confluence at Mukwe. This assessment was applied at several gauging stations in the Cubango River reaching from the station Chinhama in Angola down to the station Rundu in Namibia and for two gauging stations (Cuito Cuanavale and Dirico) in the Cuito River system. Identifying hydrological flow characteristics by analysing time series discharge data in terms of frequency, low and peak flow events, and upstream downstream linkages in the mentioned tributaries was supported by the analysis of spatially distributed climate time series and basin characteristics. The analysis of the existing datasets in this data scarce region revealed that the headwater catchments are different in runoff generation, river bed morphology, and storage capacities. The amount of delivered discharge from the Cubango is more varied in amplitude and frequency compared to the more base flow dominated Cuito discharge. Analysing spatial datasets indicated significant differences in natural landscape system features leading to different runoff generation, from fast discharge hydrographs (Cubango) to base flow driven flow dynamics (Cuito). Compiled data as well as assessed hydrological dynamics will allow for the follow-up application of process based J2000 and J2000-g hydrological models for water balance assessment and river basin rainfall-runoff modelling.
\end{abstract}

Keywords: Cubango River; Cuito River; flow duration curves; hydrological assessment; Okavango catchment; upstream-downstream analysis.

\section{A avaliação da dinâmica hidrológica no alto da bacia do rio Okavango}

Resumo: O objetivo deste trabalho é avaliar o sistema hidrológico dos afluentes da cabeceira do Okavango, ou seja, as subbacias Cuito e Cubango, e as características do fluxo do Okavango após sua confluência no Mukwe. Essa avaliação foi aplicada em várias estações de medição no rio Cubango, atingindo desde a estação Chinhama em Angola, descendo até a estação Rundu na Namíbia e duas estações de medição no sistema do rio Cuito (Cuito Cuanavale e Dirico). A identificação das características do fluxo hidrológico por meio da análise de dados de descarga de séries temporais, em termos de frequência, eventos de fluxos baixos e de picos, e as ligações a jusante e a montante nos afluentes mencionados, foi apoiada pela análise das séries temporais climáticas espacialmente distribuídas e das caracteristicas da bacia. A análise dos conjuntos de dados existentes, nessa região escassa de dados, revelou que as cabeceiras das bacias são diferentes na geração de escoamento, na morfologia do leito do rio e na capacidade de armazenamento. A quantidade de descarga distribuida pela Cubango é mais variada em amplitude e freqüência em comparação com a descarga de maior fluxo de base dominada de Cuito. A análise do conjunto de dados espaciais indicou diferenças significativas nas características do sistema de paisagem natural, levando à geração de escoamentos diferentes, de hidrogramas de descarga rápida (Cubango) até a dinâmica do fluxo de base impulsionado (Cuito). Os dados compilados, bem como a dinâmica hidrológica avaliada, permitirão dar seguimento à aplicação do processo com base nos modelos hidrológicos J2000 e J2000-g para avaliação do equilíbrio de água e modelagem da vazão fluvial na bacia do rio.

Palavras-chave: análise a montante e a jusante, avaliação hidrológica, bacia do Okavango, curvas de duração de inundação, Rio Cubango, Rio Cuito.

Received: 4 November 2013 -Accepted: 19 December 2013

\section{Introduction}

The transboundary Okavango River basin is one of the major river basins in Southern Africa. It is one of the largest River basins in the world, delivering its water southwards forming an inland endorheic Okavango Delta within the Kalahari Desert of northern Botswana. Due to varying climate and environmental conditions, runoff generation processes are diverse throughout the whole catchment, controlled by climate conditions and heterogeneously landscape characteristics.

The Okavango River basin upstream of the panhandle entrance to the Delta at
Mohembo covers an area of about $171.000 \mathrm{~km}^{2}$. About $95 \%$ of the streamflow entering the Delta is generated by two main tributaries, namely the Cubango River (basin size: $108.000 \mathrm{~km}^{2}$ ) and the Cuito River (basin size: $57.470 \mathrm{~km}^{2}$ ), both located in Angola. The ephemeral Omatako River originates in Namibia and joins the Cubango River near Rundu, but has not contributed to discharge from the Okavango for more than 50 years. Previous hydrological studies focused on the Okavango delta region, primarily due to the obvious lack of existing data for the middle and upper parts of the catchment. Up to date only a few studies address the complexity of hydrological dynamics within the entire basin (Milzow et al. 2009, Hughes et al. 2011). Other studies have shown that the hydrology of the Okavango basin is controlled by a variety of interacting tectonic (Haddon 2005, Haddon \& McCarthy 2005), geomorphologic (Gumbricht et al. 2001, Gumbricht et al. 2005, Ringrose et al. 2008), climatologic (Milzow et al. 2009), and hydrologic (Milzow et al. 2009) drivers which influence hydrological process dynamics across multiple spatio-temporal scales.

The hydrological assessments undertaken used long term measured data at the inflow entrance (Mohembo Gauge) to the Delta. They indicate that flow of 
the Okavango River is characterized by a seasonal flow regime with summer low flow periods (Oct - Nov) and winter high flow conditions (Apr - May) (Milzow et al. 2009). Mazvimavi \& Wolski (2006) pointed out that the inflow to the Delta shows a high annual variability in seasonal flooding. In addition they revealed a strong inter-annual variation of peak flows, and a long term statistical cycle, with a statistically significant maximum in the 1960s and a minimum in the late 1990s. A number of hydrological models have been applied to the Okavango Delta (e.g. Hutchinson \& Midgley 1973, Dincer et al. 1987, Gieske 1997, Manley 1997, Bauer 2006, Wolski 2006) though only a few applications model basin wide hydrological dynamics (Anderson et al. 2003, Folwell \& Farqhuarson 2006, Hughes 2004, Hughes et al. 2006). While Anderson et al. (2003) applied a modified version of the PitmanModel (Pitman 1973), which was linked to a reservoir water balance model, Hughes (2004) developed a model for the Cuito sub-catchment which was later extended to 24 sub-catchments of the entire Okavango River basin (Hughes et al. 2006). External data sources have been used to fill data gaps. The model was able to simulate low flow periods, but leads to continuous under-simulation for most of the sub-catchments, conversely overestimating the others. Anderson et al. (2003) and Milzow et al. (2009) concluded that further research was needed to improve the knowledge of the hydrological dynamics of the Okavango River basin and its tributaries and that process-based and distributive hydrological models with improved descriptions for infiltration, groundwater storage dynamics (including evaporative extraction), and lateral flow dynamics are required to better understand the dynamics of water and nutrient fluxes in time and space.

Addressing this need, this study summarizes the general hydrological characteristics of the Okavango River basin and its two main tributaries. The analysis and assessment of the existing data will lead to an enhanced system evaluation and understanding of hydrology related processes in the catchment, helping to understand differences in runoff generation and storage mechanisms.

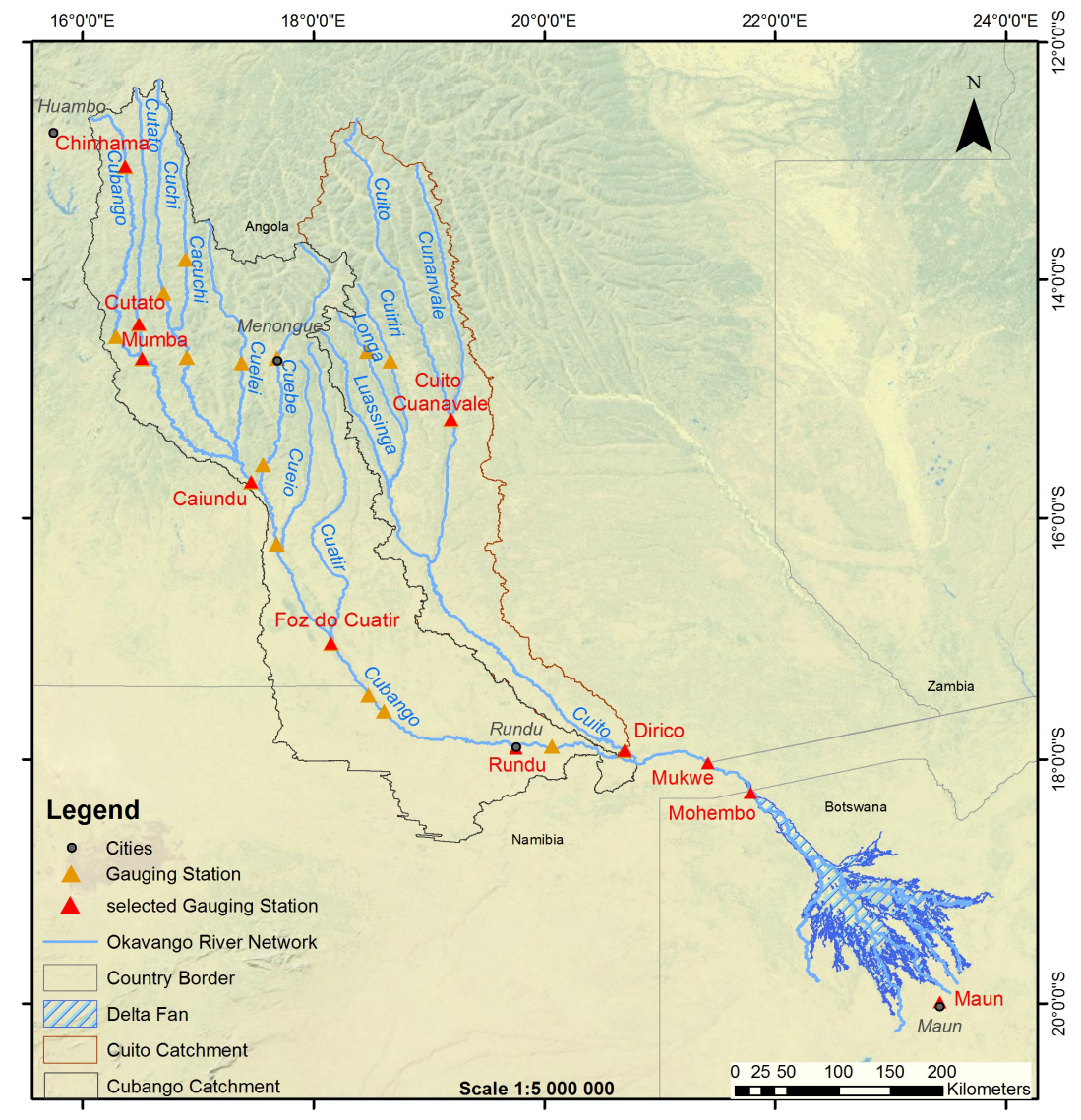

Fig. 1 Selected gauging stations for hydrological assessment and their position within the active catchment area of the Okavango basin (Data: ESRI, NIWR, GRDC, ORI).

\section{Study Area: The Okavango River Basin}

\section{Hydrology}

The Okavango River basin spans the three riparian countries of Angola, Botswana and Namibia. The source of the Okavango River is located within the southern parts of the Bié Plateau in south-central Angola. About $95 \%$ of the basin runoff is generated during the rainy season and drained south-eastwards by the two tributary rivers Cubango and Cuito, before forming the Okavango River at the confluence south of Dirico.

The Cubango catchment (basin size: $108.000 \mathrm{~km}^{2}$, flow length: $1260 \mathrm{~km}$ ) has its source at the village of Tchicala Tcholohanga (other names: Villa Nova, Chicala Choloanga) within the eastern part of the Huambo Province at an altitude of $1850 \mathrm{~m}$ asl. The main rivers feeding this tributary are, in alphabetical order, the Cacuchi, Cuatir, Cuchi, Cuebe, Cueio, Cuelei, and Cutato. The Cuito catchment (basin size: $57.470 \mathrm{~km}^{2}$, flow length: 920 $\mathrm{km}$ ) originates in the south-eastern part of the Bié Plateau between the villages of Cangoa and Sachiambe in the Moxico Province. Its main tributaries are, in alphabetical order, the Cuanavale, Cuiriri, Longa, and Luasange. On their way downstream both rivers receive numerous smaller tributaries until they cross the border to Namibia at the town of Mukwe in the Zambezi region, formerly called Caprivi). From here, the river flows southwards and after approximately 50 kilometres enters the Republic of Botswana, near the town of Mohembo. Downstream of Mohembo, the river starts to meander through the floodplains of the panhandle and eventually drains into the alluvial inland fan of the Okavango Delta (Fig. 1).

Most of the rivers in the Angolan part of the basin are perennial and generate the majority of the runoff, whereas most of the tributaries in Namibia and Botswana are ephemeral or inactive and dry (e.g. Omatako River, Dunga, Cafuma, Cafulu) (Mendelsohn \& El Obeid 2004). According to the Permanent Okavango River Basin Water Commission 
(OKACOM, 2011), the Okavango River system can be characterized as a floodplain driven system where floodwater is stored in the large floodplains sustaining the Okavango River and the Delta with water during the dry season. These floodplains are predominantly adjacent along the Cuito in Angola, the Cubango and Okavango along the Angolan-Namibian border, and the Okavango Delta in Botswana. In addition, the system is characterized as a flood pulse system in which an annual flood pulse is the dominant driver of the entire hydrological regime.

Efforts to divide the Okavango catchment into a clearly defined hydrological active drainage area and a non-active catchment area did not reach consensus in the literature. Without referring to their methodological approach in detail, Mendelsohn \& El Obeid (2004) estimate the active part of the Okavango catchment, which supplies most of the runoff, at $111.250 \mathrm{~km}^{2}$. This area includes the catchment upstream of Foz de Cuatir in the Cubango River as well as the catchment area upstream from Nankova in the Cuito catchment. Andersson et al. (2003) refer to an area of $135.000 \mathrm{~km}^{2}$ which contributes $95 \%$ of the runoff to the Okavango River. Taking the entire Cubango and Cuito catchment into account, Wilk et al. (2006) define the area which generates water for the Delta as being $165.000 \mathrm{~km}^{2}$.

\section{Climate}

The hydrology of the Okavango River catchment is controlled by the climatic conditions, especially precipitation, temperature, and the related evapotranspiration. The climate system in the Okavango catchment is controlled by complex interactions of converging airstreams from several directions. Northeast airflow (East African monsoon) together with tropical easterlies (Indian Ocean) and low level curved westerlies (Atlantic Ocean) generate precipitation during the summer months (Hudson \& Jones 2002). The complex climate conditions result in a strong precipitation gradient, decreasing from the north to the south and west to east (also referred to as septentrional extreme and meridional extreme), all of which cause a high innerand inter-annual variability (Folwell \& Farquhuarson 2006, Kghati et al. 2006, Marques 1997).

Precipitation falls exclusively as rainfall, with the highest annual values

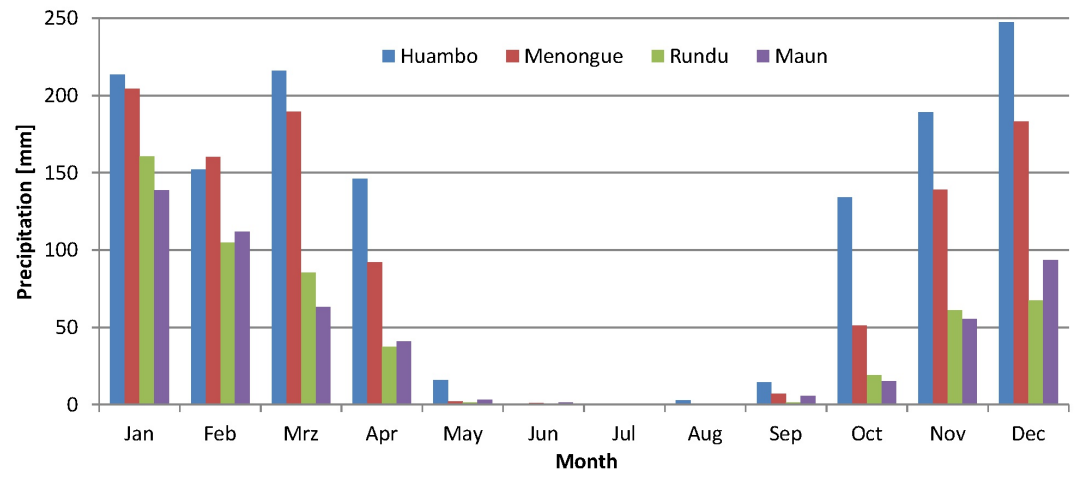

Fig. 2 Monthly average precipitation [mm] derived from station data in the study area at Huambo (Angola), Menongue (Angola), Rundu (Namibia), and Maun (Botswana) for the time period from 1962 until 1975 provided by the FAOClim 2.0 dataset (FAO 2001).

occurring in the mountainous areas of the Bié plateau, with averages reaching 1300 $\mathrm{mm}$ in Huambo, Chinguar, Cuito, and Bié. Rainfall decreases slightly with altitude, reaching average annual values of 1000 $\mathrm{mm}$ in the north-central part of the Cubango catchment around Menongue, and $900 \mathrm{~mm}$ (Cuito Cuanavale) within the east-central part of the Cuito catchment. Further downstream the mean annual precipitation continuously decreases to about $500 \mathrm{~mm}$ in Rundu and Maun (FAO 2001). Precipitation falls predominantly in the wet season from October to March or April. Most of the rainfall in the northern regions occurs in December and January (Fig. 2). In the southern area of the Okavango catchment, the months of January and February have the highest amount of precipitation (OKACOM 2011, Kgathi et al. 2006, FAO 2001), occurring as thunderstorms with high temporal and spatial variability (Marques 1997). The dry season, lasting from May to September, is characterized by the absence of significant precipitation events (Fig. 2)

The mean annual temperature in the Okavango River basin is around $20{ }^{\circ} \mathrm{C}$ and increases slightly from the north to the south (Mendelsohn and El Obeid 2004). Maximum monthly temperatures vary between $22-24{ }^{\circ} \mathrm{C}$ during summer (October-January), whereas the monthly averages drop to $15-17^{\circ} \mathrm{C}$ in the peak dry season between June and August. With daily maxima of $30-35{ }^{\circ} \mathrm{C}$, the highest daily temperatures occur during August to March in the southern parts of the Okavango catchment, which is close to the daily maximum temperatures in the headwater region of the catchment (30-32 ${ }^{\circ} \mathrm{C}$ ). The lowest temperatures occur during the winter months with mean daily minimums ranging from $7-10{ }^{\circ} \mathrm{C}$ in the southern parts and $3-8{ }^{\circ} \mathrm{C}$ in the northern parts of the catchment (OKACOM 2011, Kgathi et al. 2006, Marques 1997). Although rare, night frosts may occur in the southern part of the Okavango River basin during winter months. According to Marques (1997), annual evaporation is around $1900 \mathrm{~mm}$ at higher altitude areas within the headwater region of the catchment. The annual evaporation sum increases up to $2.000 \mathrm{~mm}$ at the lower altitudes and in the southern catchment areas, where average annual rainfall ranges between $500 \mathrm{~mm}$ and $700 \mathrm{~mm}$. The highest evaporation occurs during the end of the drought period, between September and October. An overview of average records of monthly pan evaporation and potential evapotranspiration calculated through different methods is presented by Marques (1997) and Mendelsohn \& el Obeid (2004).

\section{Geology, river morphology and soils}

The geological structures of the northern parts of the Cubango basin are characterized by Pre-Cambrian igneous and metamorphic rocks within the area of the most pronounced relief. The igneous rocks include granites, porphyries, and porphyrites and are found in the northwestern region of the headwaters. Metamorphic rocks (represented by the basement complex) occur at the northeastern boundaries of the Cubango catchment and include gneisses, metamorphic xistos, quarzites, and crystalline calcareous, all of which tend to have a low hydraulic conductivity (OKACOM 2011, Bareslavski 1997).

Sedimentary formations from the 
Kalahari Superior formation cover the majority of the flat north-eastern and southern parts of the Cubango and, especially, the Cuito basin. The thick layers are sandy, with some levels of gravel deposits and lateritic layers overlaying polymorphic sandstone and quartzite from the lower Kalahari formation (Bareslavski 1997). According to Hughes et al. (2006), the area around Menongue represents the transitional zone between the hard Pre-Cambrian rocks in the western parts of the Cubango and the layered Kalahari sands in the eastern region.

In terms of river morphology, the Cubango system comprises small valleys with a steep gradient in the headwaters which tend to become wider further downstream. Within the valleys, extensive sandy terraces and floodplains have been formed. The valley bottoms of the incised valleys in the headwater areas are mostly covered by permanent wet grassland on fluvisol type soils, with the occurrence of exposed granitic and gneissic bedrocks. The deep valleys within the Cuito catchment are generally wide with long planes, peat filled swamps, gleysols, and fluvisol soil types in the valley bottoms. They retain water longer than the sandy valley soils of the Cubango River and force the river to meander in its floodplains. Within these valleys vegetation is sparse with short grass and without tree cover (OKACOM 2011, Kgathi et al. 2006). The remaining areas of the Cubango and Cuito catchments are dominated by either sandy arenosols or ferralsols (OKACOM 2011). Due to topography and the high proportion of granitic soils within the Cubango catchment, runoff generation mechanisms are widely driven by surface runoff in the headwaters. In contrast, the Cuito catchment is generally flatter and dominated by Kalahari sands. As such, most of the runoff consists of both groundwater and surface runoff.

\section{Vegetation}

As well as having the highest amount of annual precipitation, the most northwestern headwaters of the Cubango catchment are also dominated by the so called "planalto" grassland. According to Kgathi et al. (2006), the headwater region comprises extensive upland grasslands e.g. Loudetia simplex and is intersected by small streams. Some patches of eucalyptus woodland can be found at the source area of the Cubango River. The general vegetation pattern within the northern Cubango and Cuito catchment areas can be characterized by the predominantly occurring, wetter, Zambezian Miombo woodlands (dominated by Brachystegia, Julbernardia and Isoberlinia) and reed swamps along the tributaries. These woodlands decrease in density as one descends in both altitude and precipitation gradient towards the south (Mendelsohn \& el Obeid 2004, Kgathi et al. 2006, OKACOM 2011). According to Mendelsohn \& el Obeid (2004), dense evergreen Brachystegia woodland (e.g. Julbernardia paniculata, Pteleopsis anisoptera and Cryptosepalum sp.) covers most of the eastern portion of the northern basin. The central part of the Cubango and Cuito basin has been cleared (especially areas around settlements) for cultivation, and the remaining natural vegetation is characterized by zones of open Miombo (Brachystegia) savannah permeated with swampy areas. In the southern and dryer parts of the Cubango and Cuito catchment as well as along the Okavango until it enters the panhandle, a transition zone which characterized by an increased occurrence of dry deciduous Burkea woodland (e.g. Burkea africana, Pterocarpus angolensis, Baikiaea plurijuga, Terminalia sericea) is found (OKACOM 2011, Kgathi et al. 2006, Mendelsohn \& el Obeid 2004). Sparse gallery woodlands are characteristic along the southern river banks, where Hyphaene benguellensis is common. In the lower Cuito valleys and close to the junction with the Cubango, Cyperus papyrus occurs. The banks of the Okavango River are dominated by Phragmites and Papyrus (Hughes \& Hughes 1992).

\section{Data and Methods}

This section provides an overview about existing datasets which were considered and analysed in this study. The first part gives an overview of the hydrometeorological datasets which have been used for the hydrological assessment of the Okavango River catchment and its main tributaries. The second part describes the geodata which provided spatial information for the assessment and the system analysis (especially soil, vegetation, landuse and relief analysis). The data used for this study are provided online through the Okavango Basin Information System (OBIS) (http://leutra.geogr.uni-jena.de/obis/ metadata/start.php). Within the Methods section we describe the station selection for the hydrological assessment as well as the hydrological assessment itself.

\section{Data}

\section{Hydro-meteorological data}

\section{Discharge data}

Hydrological time series for the Okavango basin were extracted from different sources. For the Angolan section of the catchment, hydrological time series were provided by the National Institute of Water Resources of Angola (NIWR) in Luanda. The dataset includes daily mean discharge data $\left[\mathrm{m}^{3} \mathrm{~s}^{-1}\right]$ and daily water level data [m] for a total of 20 gauging stations. The records were partially preprocessed and quality checked by the Norwegian Water Resources and Energy Directorate (Norwegian Water Resources and Energy Directorate 2004). The time series used for the assessment range from 1962 (hydrometric station at Dirico) to 1975. This period forms the main Angolan data collection period, as after this there are considerable gaps in the data, during the Angolan civil war. Due to the lack of any additional actual discharge data, data from this period are the base for all Angolan water use, environmental water protection, and flood protection, planning, as well as for answering hydro-statistical questions (Norwegian Water Resources and Energy Directorate 2004).

Discharge Data was also provided by the Global Runoff Data Centre (GRDC). Here, daily discharge records starting in the middle/late 1940s and ending in the late 1990s. Time series of discharge are available for the gauging station at Rundu at the Cubango River (before the confluence of the Cuito and the Cubango), the station at Mukwe after the confluence of the Cubango and Cuito Rivers as well as for the station at Mohembo. All discharge records were tested for gaps, homogeneity, and consistency, using regression analysis and double sum analysis. Table 1 gives a summarized overview of the discharge time series including the station location, the measurement period, and the corresponding tributary, as well as the mean discharge for the period of record. The locations of the gauging stations in the tributaries are shown in Figure 1.

Monthly discharge data was also extracted from the Spatial and Time Series 
Table 1. Stations with time series of daily discharge within the Okavango river catchment (including the tributaries of the Cubango and Cuito) and associated information (Data: NIWR, GRDC). Note: The mean discharge is calculated for the given period of record.

\begin{tabular}{|c|c|c|c|c|c|c|c|}
\hline Station & Tributary & Lat & Lon & $\begin{array}{l}\text { Period of } \\
\text { record } \\
\text { (including } \\
\text { gaps) }\end{array}$ & $\begin{array}{l}\text { Catchment size } \\
\qquad\left(\mathrm{km}^{2}\right)^{\mathrm{a}}\end{array}$ & Data provider & $\begin{array}{c}\text { Mean } \\
\text { discharge } \\
\left(\mathrm{m}^{3} \mathrm{~s}^{-1}\right) \text { (period } \\
\text { of record) }\end{array}$ \\
\hline Longa Ponte & Cuito - Longa & $14: 42: 0 \mathrm{~S}$ & $18: 28: 0 \mathrm{E}$ & $\begin{array}{c}19.10 .1966- \\
31.05 .1969\end{array}$ & 796 & NIWR & 4.7 \\
\hline $\begin{array}{l}\text { Menongue } \\
\text { Luahuca }\end{array}$ & $\begin{array}{l}\text { Cubango - } \\
\text { Luahuca }\end{array}$ & $14: 40: 0 \mathrm{~S}$ & $17: 41: 0 \mathrm{E}$ & $\begin{array}{c}01.10 .1968- \\
30.09 .1974\end{array}$ & 1001 & NIWR & $1.4^{\mathrm{d}}$ \\
\hline Chinhama & Cubango & $13: 3: 0 \mathrm{~S}$ & $16: 22: 0 \mathrm{E}$ & $\begin{array}{c}01.10 .1966- \\
30.06 .1975\end{array}$ & 1597 & NIWR & 19.7 \\
\hline Cuiriri & $\begin{array}{l}\text { Cubango - } \\
\text { Cuiriri }\end{array}$ & $14: 41: 0 \mathrm{~S}$ & $18: 40: 0 \mathrm{E}$ & $\begin{array}{c}01.10 .1967- \\
30.09 .1973\end{array}$ & 1749 & NIWR & 8.1 \\
\hline Camue & $\begin{array}{l}\text { Cubango - } \\
\text { Cacuchi }\end{array}$ & $13: 50: 0 \mathrm{~S}$ & $16: 53: 0 \mathrm{E}$ & $\begin{array}{c}16.01 .1969- \\
02.07 .1975\end{array}$ & 2649 & NIWR & 11.3 \\
\hline Cutato & Cubango & $14: 22: 0 \mathrm{~S}$ & $16: 30: 0 \mathrm{E}$ & $\begin{array}{c}15.03 .1968- \\
08.07 .1975\end{array}$ & 3732 & NIWR & 24.2 \\
\hline $\begin{array}{l}\text { Menongue } \\
\text { Cuebe }\end{array}$ & $\begin{array}{l}\text { Cubango - } \\
\text { Cuebe }\end{array}$ & $14: 40: 0 \mathrm{~S}$ & $17: 42: 0 \mathrm{E}$ & $\begin{array}{c}01.10 .1967 \text { - } \\
31.08 .1974\end{array}$ & 4771 & NIWR & $21.3^{d}$ \\
\hline Missao Velha & $\begin{array}{l}\text { Cubango - } \\
\text { Cuelei }\end{array}$ & $14: 41: 0 \mathrm{~S}$ & $17: 22: 0 \mathrm{E}$ & $\begin{array}{c}19.03 .1968- \\
25.11 .1974\end{array}$ & 5950 & NIWR & 17 \\
\hline $\begin{array}{l}\text { Vila Artur } \\
\text { de Paiva }\end{array}$ & Cubango & $14: 29: 0 \mathrm{~S}$ & $16: 17: 0 \mathrm{E}$ & $\begin{array}{c}01.10 .1967- \\
30.09 .1975\end{array}$ & 7434 & NIWR & 72.1 \\
\hline Cuchi & $\begin{array}{l}\text { Cubango - } \\
\text { Cuchi }\end{array}$ & $14: 40: 0 \mathrm{~S}$ & $16: 54: 0 \mathrm{E}$ & $\begin{array}{c}08.03 .1968- \\
07.07 .1975\end{array}$ & 9297 & NIWR & 39.5 \\
\hline Capico & Cuango - Cuebe & $15: 33: 0 \mathrm{~S}$ & $17: 34: 0 \mathrm{E}$ & $\begin{array}{c}01.10 .1967- \\
17.07 .1975\end{array}$ & 10257 & NIWR & $22.7^{\mathrm{d}}$ \\
\hline Mumba & Cubango & $14: 40: 0 \mathrm{~S}$ & $16: 31: 0 \mathrm{E}$ & $\begin{array}{c}26.06 .1968- \\
30.09 .1973\end{array}$ & 12560 & NIWR & 66.6 \\
\hline $\begin{array}{c}\text { Cuito } \\
\text { Cuanavale }\end{array}$ & $\begin{array}{c}\text { Cuito - } \\
\text { Cuanavale }\end{array}$ & $15: 33: 0 \mathrm{~S}$ & $19: 12: 0 \mathrm{E}$ & $\begin{array}{c}\text { 01.07.1967 - } \\
26.01 .1972\end{array}$ & 21610 & NIWR & $118.9^{d}$ \\
\hline Caiundo & Cubango & $15: 42: 0 \mathrm{~S}$ & $17: 28: 0 \mathrm{E}$ & $\begin{array}{c}01.10 .1967- \\
20.07 .1975\end{array}$ & 38755 & NIWR & $145.3^{d}$ \\
\hline Muccundi & Cubango & $16: 13: 0 \mathrm{~S}$ & $17: 41: 0 \mathrm{E}$ & $\begin{array}{c}\text { 01.10.1967 - } \\
20.07 .1975\end{array}$ & 50510 & NIWR & 170.3 \\
\hline Foz do Cuatir & Cubango & $17: 2: 0 \mathrm{~S}$ & 18:9:0 E & $\begin{array}{c}\text { 01.01.1967 - } \\
15.10 .1975\end{array}$ & 57130 & NIWR & 176.3 \\
\hline Dirico & Cuito & $17: 56: 0 \mathrm{~S}$ & $20: 42: 0 \mathrm{E}$ & $\begin{array}{c}25.03 .1962- \\
13.07 .1975\end{array}$ & 57300 & NIWR & 162.1 \\
\hline Chissombo & $\begin{array}{l}\text { Cubango - } \\
\text { Chissombo }\end{array}$ & $17: 28: 0 \mathrm{~S}$ & $18: 29: 0 \mathrm{E}$ & $\begin{array}{c}01.10 .1969- \\
30.09 .1974\end{array}$ & 70600 & NIWR & 123.3 \\
\hline Rundu ${ }^{b}$ & Cubango & $17: 55: 0 \mathrm{~S}$ & $19: 45: 0 \mathrm{E}$ & $\begin{array}{c}01.10 .1945- \\
04.09 .2000\end{array}$ & 103807 & GRDC & 165 \\
\hline Sambio & Cubango & $17: 53: 0 \mathrm{~S}$ & 20: 4:0 E & $\begin{array}{c}01.10 .1966- \\
12.07 .1975\end{array}$ & 105700 & NIWR & 167.1 \\
\hline Mukwe ${ }^{b}$ & Okavango & $18: 1: 0 \mathrm{~S}$ & $21: 21: 0 \mathrm{E}$ & $\begin{array}{c}01.10 .1949- \\
01.09 .1998\end{array}$ & 168468 & GRDC & 304.1 \\
\hline Mohembo ${ }^{b}$ & Okavango & $18: 16: 0 \mathrm{~S}$ & $21: 47: 0 \mathrm{E}$ & $\begin{array}{c}01.10 .1974- \\
01.09 .2002\end{array}$ & 171000 & GRDC & 237.3 \\
\hline
\end{tabular}

a Derived from SRTM-DEM data (USGS 2003)

${ }^{b}$ Calculated size is excluding the Omatako river drainage area

c Period of record varies for each of the listed hydrometric stations

d These stations were re-established in 2012 by funds provided by the project "The Future Okavango (TFO)" funded by the German Ministry of Education and Research (BMBF). The re-established stations are located on the following tributaries: the Luahuca River in Menongue, the Cuebe River in Menongue, the Cuebe River in Capico, the Cubango River in Caiundu, the Cuchi River in Cuchi, and the Cuito River in Cuito Cuanavale (planned). 
Information Modelling Software (SPATSIM) dataset which was developed at the Institute for Water Research at the Rhodes University (IWR). It contains monthly mean values of discharge and water level for a variety of gauging stations within the Okavango River catchment (Hughes \& Forsyth 2006, Andersson et al. 2003).

\section{Meteorological Data}

To describe and analyse the climate within the study area, meteorological data including monthly values of precipitation $[\mathrm{mm}]$, temperature $\left[{ }^{\circ} \mathrm{C}\right]$, and relative humidity [\%] were extracted from the FAOClim 2.0 database. Additionally, the database also provides long-term averages (1960-1990) and time series data for temperature, precipitation, and relative humidity at a monthly resolution (Hijmans et al. 2005). In total 19 stations of the FAOClim 2.0 database are located within the Okavango Basin (Angola: 6; Namibia: 10, and Botswana: 4). Most of them having data available for less than 10 years and/or for only a limited number of climate parameters.

Another dataset including monthly precipitation data for 162 stations (8 within the catchment) is the data from the Nicholson African Rainfall database found within the SPATSIM Package. The dataset, which is based on data from the National Center for Atmospheric Research (NCAR) Data Support Section, covers the time period from 1959 to 1972 (Andersson et al. 2003, Wilk et al. 2006).

In addition, two time series for the stations of Huambo and Menongue (closest stations related to the Okavango River catchment) were collected from the
Global Surface Summary of the Day (GSOD) dataset, which is archived at the National Climatic Data Center (NCDC). Unfortunately these time series contained data gaps which were too long to extract reliable information over a certain time period from. However, they did provide data which could be used to validate extreme runoff events during the occurrence of high rainfall. Provided by the Angolan National Institute of Meteorology and Geophysics (INAMET), paper copies of precipitation data including single, non-continuous time period data from the pre-civil-war period were acquired and digitized. In total, 99 stations were processed. Further sources of climate information are global climate network data, such as from Word Meteorological Organization (WMO) stations spread over the southern African

Table 2. Overview of the meteorological stations and the measured climate elements $(p=$ precipitation, $t=$ temperature, $r H=$ relative humidity, vap. pressure $=$ vapor pressure). The temporal resolution and the period of record is also provided for each station.

\begin{tabular}{|c|c|c|c|c|c|}
\hline Source & Country & Station & Climate Element & Resolution & $\begin{array}{l}\text { Period of record } \\
\text { (including gaps) }\end{array}$ \\
\hline & & Cuito Cuanavale & $\mathrm{p}$ & monthly & Jan. 1944 - Jun. 1975 \\
\hline & & Dirico & $\mathrm{p}$ & monthly & Jan. 1955 - Jul. 1975 \\
\hline & & Artur de Paiva & $\mathrm{p}$ & monthly & Jan. 1950 - Dec. 1972 \\
\hline & & $\begin{array}{l}\text { Menongue (former } \\
\text { Serpa Pinto) }\end{array}$ & $\begin{array}{l}p, t, r h, \text { dew point, } \\
\text { vap. pressure }\end{array}$ & monthly & Apr. 1940 - Aug. 1984 \\
\hline & & Chitembo & $\mathrm{P}$ & monthly & Jan. 1942 - Jul. 1975 \\
\hline & Angola & Chinguar & $\mathrm{p}$ & monthly & Jan. 1937 - Dec. 1972 \\
\hline & & Huambo & $\begin{array}{l}\mathrm{p}, \mathrm{t}, \mathrm{rh}, \text { dew point, } \\
\text { vap. pressure }\end{array}$ & monthly & Jan. 1940 - Jun 1975 \\
\hline \multirow[t]{6}{*}{ FAOClim } & & Bie & t, rh, vap. pressure & monthly & Jan. 1930 - Dec. 1972 \\
\hline & & Kuito & $\mathrm{p}$ & monthly & Jan. 1930 - Dec. 1972 \\
\hline & & Mavinga & $p, t$, rh, vap. pressure & monthly & Jan. 1954 - Dec. 1974 \\
\hline & & Andara & $\mathrm{p}$ & monthly & Jul. 1922 - Apr. 1998 \\
\hline & Namibia & Kuring-Kuru & $\mathrm{p}$ & monthly & Jul. 1910 - Sep. 1997 \\
\hline & & Rundu & $\mathrm{p}$ & monthly & Jan. 1940 - Apr. 1998 \\
\hline \multirow{4}{*}{ WMO } & Angola & Huambo & $\begin{array}{l}\mathrm{p}, \mathrm{t}, \text { wind, pressure, } \\
\text { visibility, dew point }\end{array}$ & daily & $\begin{array}{l}01.02 .1955- \\
21.05 .2010\end{array}$ \\
\hline & & Menongue & $\begin{array}{l}\mathrm{p}, \mathrm{t}, \text { wind, pressure, } \\
\text { visibility, dew point }\end{array}$ & daily & $\begin{array}{l}\text { 03.07.1957 - } \\
\text { 17.09.1981 }\end{array}$ \\
\hline & Namibia & Rundu & $\begin{array}{l}\mathrm{p}, \mathrm{t}, \text { wind, pressure, } \\
\text { visibility, dew point }\end{array}$ & daily & $\begin{array}{l}02.10 .1945 \text { - } \\
19.04 .2011\end{array}$ \\
\hline & Botswana & Maun & $\begin{array}{l}\mathrm{p}, \mathrm{t}, \text { wind, pressure, } \\
\text { visibility, dew point }\end{array}$ & daily & $\begin{array}{l}01.10 .1980- \\
25.09 .2011\end{array}$ \\
\hline
\end{tabular}


region. Here, time series from 25 climate stations and 17 precipitation stations were processed. The database was complemented with data for the Namibian part of the Okavango basin, received for the most part from the Ministry of Water, Agriculture and Forestry of Namibia (MWAF), and also in part from farmers and agricultural projects. All these data have been preprocessed and are available as homogenized and quality checked datasets.

\section{Geodata}

Geodatasets in raster and vector format have been evaluated, corrected, and processed in order to support the hydrological system analysis of the Okavango basin. The datasets provide crucial Information about the spatial distribution of process related landscape characteristics. All datasets shown in Table 2 were analysed to contribute to the work of this paper. Due to the civil war in Angola from 1975 to 2002, there is a lack of data from field studies and field surveys. The datasets provided have been qualitychecked to fulfil the requirements of the hydrological system analysis as presented by Flügel (1995). The SRTM-DEM (USGS 2003) was corrected, e.g. filling of sinks, and processed, to derive relief parameters such as exposition, slope, watersheds, and river network. Land use and cover (LULC) information for the Okavango River basin was extracted from the global land cover dataset GlobCover2009 (Arino et al. 2012), and complemented by analysis from MODIS (MCD12Q1) annual land cover products (Friedl 2010, NASA 2010). For validation purposes, and to better assess spatio-temporal surface structures and change dynamics, remote sensing images from Landsat (MMS, ETM + ) were analysed for selected small scale test catchments, applying a multi-temporal object based classification approach. Geological information for the Okavango was taken from the EPSMO Project (Verissimo 2009). More detailed information about the geological setting within the Angolan part of the catchment was provided by hardcopy lithological maps, which have been digitized (Servico Geologico de Angola 1988). Soil information was derived from the FAOSOTERSAF (Dijkshoorn et al. 2008) dataset, providing information about the major soil groups and their soil specific parameters e.g. texture or bulk density. The relevant digital GIS data layers present in OBIS were also quality checked (ButchartKuhlmann 2012).

\section{Methods}

\section{Station Selection}

Since the discharge volume of the Okavango reaches its maximum at Mukwe gauging station (Namibia), time series of daily discharge obtained from the hydrometric station at Mukwe (Namibia) were analysed for the period starting in January 1950 and ending in December 1997. The objective of this analysis was to assess and analyse the hydrological dynamics of the entire Okavango River basin. At the Mukwe station, the Okavango River drains an area of approximately $168.468 \mathrm{~km}^{2}$, including the drainage areas of the Cubango and the Cuito River basins. Further downstream the discharge decreases slightly until its entrance into the panhandle at the Mohembo gauging station in Botswana.

For a comparative statistical analysis of the hydrological dynamics between the two tributary catchments of the Cubango and the Cuito, time series data recorded at the gauging stations at Rundu (Cubango River, drainage area: $103.807 \mathrm{~km}^{2}$ ) and Dirico (Cuito River, $57.300 \mathrm{~km}^{2}$ ) were used. Both stations are located upstream of the junction of the two tributaries to the Okavango River (Fig. 1). For comparison, only time series data from April 1962 until July 1975 were analysed due to the relatively short overlapping period (Table 1).

According to $\mathrm{Wu}$ et al. (2009), upstream-downstream relationships of discharge, its severity, and frequency are critical to understanding how single extreme events, e.g. droughts and floods, propagate over time and space. Furthermore insight about these relationships can be used to resolve water disputes and trigger the development of mitigation strategies. They also provide information which help to understand changes within the basin environment (Wu et al. 2009). A crucial and challenging step regarding the analysis of upstream-downstream relations within the Cubango and the Cuito catchment was the selection of the best suited gauging stations. With regard to the limited availability of time series data at the hydrometric stations of Longa and Cuiriri, only time series data recorded at the gauging stations Cuito Cuanavale and Dirico from 1967 to 1975 were considered for the analysis of upstream-downstream relationships within the Cuito River basin. For analysing the upstream-downstream relationships in the Cubango catchment, the stations of Chinhama (Tributary: Cubango), Mumba (Cubango), Cuchi (Cuchi), Caiundu (Cubango), Capico (Cuebe), Muccundi (Cubango), Foz do Cuatir (Cubango), Chissombo (Cubango), Rundu (Cubango), and Sambio (Cubango) were considered within the time period from October 1967 to May 1975.

\section{Hydrological Assessment}

To represent and compare the tributaries, the statistical indicators as well as the Environmental Flow Components (EFC) and Flow Duration curves (FDC) were calculated, aggregated, and evaluated for the assessment of hydrological dynamics. The mean discharge, as a statistical indicator, represents the mean river discharge over a specific period of time. The annual mean maximum discharge (MHQ) is representing the mean of the highest discharge values per month of a year over a specific time period. Besides this we computed the annual mean minimum discharge (MNQ), as the mean of the lowest discharge values per month of a year over a specific time period. As a measure for the environmental contingency of discharge, the annual coefficient of variation (CV) was calculated (Richter et al. 1996). The CV is defined as the standard deviation (SD) divided by the mean discharge (Mahon 1987).

For the general description of the hydrological dynamics and the assessment of the hydrological characteristics five different types of environmental flow components (EFC) as indicators for changing hydrological dynamics were applied in this study. The EFCs were calculated with the Indicators for Hydrologic Alteration Software (IHA) (Richter et al. 1996; Gao et al. 2009). All daily flows fall within one of the five EFC categories of Extreme Low Flow, Low Flow, High Flow pulses, Small Floods, and Large Floods, calculated by a complex algorithm which parses the hydrograph based on predefined thresholds (The Nature Conservancy 2009). A summary of ecological roles that each of the five environmental flow components may play in a river system are presented in detail in Richter and Thomas (2007). In this study, High Flow pulses include all flows exceeding the 75th percentile of daily flows for a given period of time. Low Flows refer to all flows that are below the 25th percentile of daily flows within the investigated period of time. Between these two flow levels, a High Flow will begin when flow increases 
by more than $25 \%$ day and will end when flow decreases by less than $10 \% /$ day. A Small Flood event is defined as an initial high flow with a peak flow greater than a two year returning period. A Large Flood event is defined as an initial high flow with a peak flow greater than a 10 year return interval event. All initial high flows which are not classified as Small Floods or Large Floods are classified as High Flow pulses. Extreme Low Flows in contrast, are defined as an initial low flow below $10 \%$ of daily flows within the time series. All initial Low Flows which are not classified as Extreme Low Flows are classified as Low Flows with an upper boundary at the 25 th percentile.

To represent the relationship between the magnitude and frequency of daily discharge and to provide an estimate of the percentage of time that the measured daily flow is likely to equal or exceed one of the five EFC categories we computed Flow Duration curves for the investigated tributaries. The FDC is a suitable measure to assess discharge variability and are explained in detail by Castellarin et al. (2012) as well as Viola et al. (2011).

\section{Hydrological characteristics of the Upper Okavango Basin}

\section{Okavango (Mukwe)}

The mean daily discharge (Fig. 3) during the analysed period of time is $306 \mathrm{~m}^{3} \mathrm{~s}-1$ (Median: $247 \mathrm{~m}^{3} \mathrm{~s}-1$ ) with a $\mathrm{SD}$ of $182 \mathrm{~m}^{3} \mathrm{~s}-1$. A mean annual value of 0.6

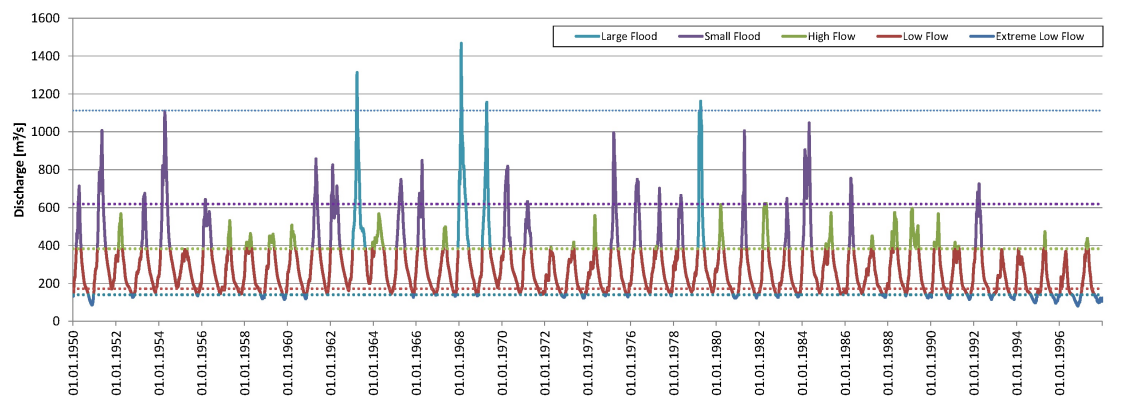

Fig. 3: Observed daily runoff of the Okavango river for the time period of 1950 until 1998 at Mukwe and the thresholds for the environmental flow components (EFC) categories as descript within the text (horizontal lines) (Data: GDRC).

indicates a high annual flow variability of the Okavango River at Mukwe. The year with the highest annual mean discharge was 1963 and the year with the lowest annual mean discharge was 1996 , with values of approximately $499 \mathrm{~m}^{3} \mathrm{~s}-1$ and $174 \mathrm{~m}^{3} \mathrm{~s}-1$, respectively. The highest daily discharge volume was observed on February 6th 1968 with a peak flow of $1467 \mathrm{~m}^{3} \mathrm{~s}-1$, which is 4.5 times higher in magnitude than the long term annual mean discharge. This event was caused primarily by unusually early floods in the tributaries of the Cubango and the Cuito River (OKACOM 1998), and has a return period of in excess of 50 years. The MHQ at Mukwe is $353 \mathrm{~m}^{3} \mathrm{~s}-1$ (SD: $91 \mathrm{~m}^{3} \mathrm{~s}-1$ ). The MNQ is $263 \mathrm{~m}^{3} \mathrm{~s}-1$ (SD: $59 \mathrm{~m}^{3} \mathrm{~s}-1$ ). The linear trend analysis of the time series also shows a significant decrease in discharge, a $32 \%$ over the 48 years analysed.

Figure 3 shows the observed daily discharge of the Okavango river for the analysed period of time at Mukwe and the different thresholds for the EFC categories. A High Flow is corresponding to a discharge threshold of $383 \mathrm{~m}^{3} \mathrm{~s}^{-1}$ within the analysed 48 years of time. The Low Flows refer to all flows that are exceeding a discharge threshold of $172 \mathrm{~m}^{3} \mathrm{~s}^{-1}$ and are below the High Flow threshold. All discharge which is not greater than the Low Flow threshold are classified as Extreme Low Flows which are below a discharge value of $172 \mathrm{~m}^{3} \mathrm{~s}^{-1}$. The threshold for a Small Flood event with a two year returning period is equivalent to a discharge exceeding $619 \mathrm{~m}^{3} \mathrm{~s}^{-1}$. A Large Flood with a 10 year return interval is corresponding to a discharge value which is above $1.113 \mathrm{~m}^{3} \mathrm{~s}^{-1}$. In total, four Large Floods in excess of $1.113 \mathrm{~m}^{3} \mathrm{~s}^{-1}$ occurred during the months of February and May within the given period. Three of these extreme pulses occurred during the 1960 s and one at the end of the 1970s. These Large

Table 3. Obtained and processed geodatasets contributing to the hydrological assessment and hydrological system analysis.

\begin{tabular}{|c|c|c|c|c|}
\hline Dataset & Product & Format & Spatial Resolution & Source \\
\hline SRTM-DEM & SRTM-DEM & Raster & $90 \times 90 \mathrm{~m}$ & United States Geological Survey (USGS) (2003) \\
\hline Landuse & GLOBCOVER 2009 & Raster & $300 \times 300 \mathrm{~m}$ & European Space Agency (ESA)(2009) \\
\hline Landuse & Landsat imagery & Raster & $80 \times 80 \mathrm{~m}$ & Global Land Survey (GLS) (2008) \\
\hline Landuse & Landsat imagery & Raster & $30 \times 30 \mathrm{~m}$ & Global Land Survey (GLS) (2008) \\
\hline Soil & SOTERSAF & Vector & & Food and Agricultural Organization (FAO) (2008) \\
\hline Geology & $\begin{array}{l}\text { Geology of the Okavango } \\
\text { Active Catchment Area } \\
\text { (OACA) }\end{array}$ & Vector & $1: 5.000 .000$ & $\begin{array}{l}\text { Environmental Protection and Sustainable Management } \\
\text { of the Okavango River Basin (EPSMO) (2009) }\end{array}$ \\
\hline Geology & Geological Map of Angola & Vector & $1: 1.000 .000$ & Servico Geologico de Angola (1988) \\
\hline
\end{tabular}




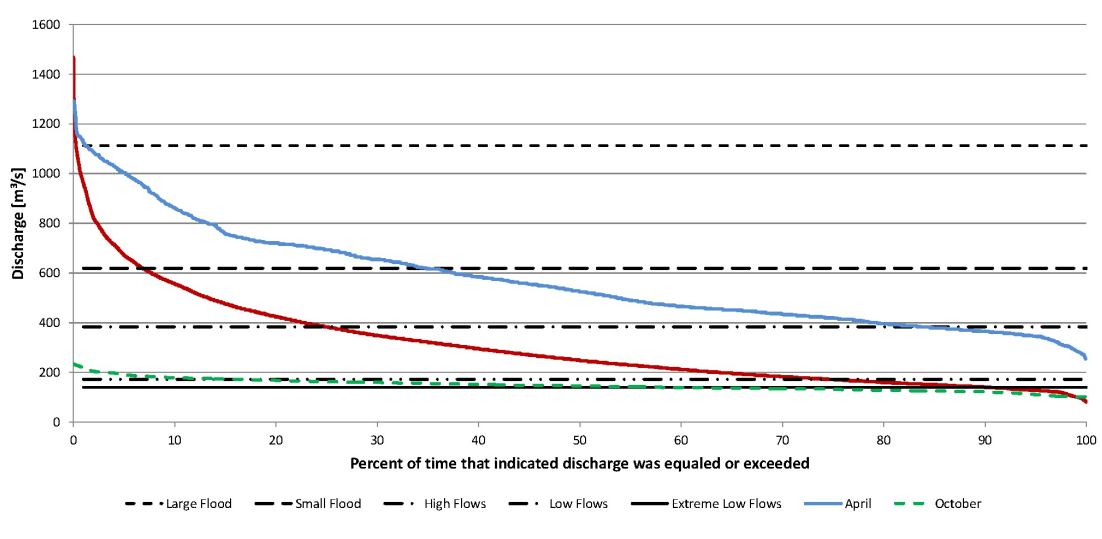

Fig. 4: Daily flow duration curve (FDC) for runoff at Mukwe (1950-1998, red line) and daily FDCs for the months of April and October within the time period 1950-1998. The horizontal lines represent the environmental flow components (EFC) categories of the discharge at Mukwe (1950-1998) (Data: GRDC).

Flood events occurred during only $0.24 \%$ of the time period assessed, however, whereas discharge classified as Small Floods occurred in over $5.9 \%$ of the time period. The general flow characteristics changed during the 1970s when predominantly Small Floods, caused by precipitation in the headwater areas of the Cubango and Cuito River catchment, occurred. The majority of the flow regime in the 1980s and the 1990s is characterized by Low Flows and High Flow pulses. Figure 3 also indicates that the frequency and number of Extreme Low Flows has been increasing since the mid-1980s, while the occurrence of Small and Large Floods has been decreasing in frequency and amplitude compared to the time period prior to 1980 .

The analysis of the annual hydrographs shows that monthly discharge is highest between January and June. The rising limb and the peak flows, caused by rainfall events in the headwater catchments of the Cuito and especially Cubango rivers, reach the downstream areas during these months. The highest monthly mean discharge occurs during April with a mean of $571 \mathrm{~m}^{3} \mathrm{~s}^{-1}$. The lowest monthly mean discharge of $146 \mathrm{~m}^{3} \mathrm{~s}^{-1}$ occurs between October and November, i.e. at the end of the dry season when the Cubango and especially the Cuito rivers predominantly carry base flow to the Okavango River (see next section). Table 3 gives a summarized overview of the mean monthly discharge, its standard deviation, and the coefficient of variation of the Okavango River discharge at Mukwe within the investigated period of time.

Figure 4 represents the FDC of daily flows from 1950 - 1998 for discharge at Mukwe (1950-1998). Figure 4 also includes daily FDCs for the months of April and October within the time period 1950-1998. For April the FDC (Fig. 4) shows a steep gradient which reflects the broader range of flows measured. It also indicates a relatively high variability of flow if compared to the long term mean represented by the extreme high and low flows in April. The FDC shows the relative low variation in flow during October at the end of the dry season (Fig. 4).

\section{Cubango and Cuito River System}

The statistical analysis shows a mean annual discharge of $162 \mathrm{~m}^{3} \mathrm{~s}^{-1}$ for the Cuito and $188 \mathrm{~m}^{3} \mathrm{~s}^{-1}$ for the Cubango. The mean annual discharge exceeded $41 \%$ within the Cuito and $33 \%$ of the time period within the Cubango River. The discharge variability is represented by a standard deviation of daily discharge by $178 \mathrm{~m}^{3} \mathrm{~s}^{-1}$ for the Cubango and $51 \mathrm{~m}^{3} \mathrm{~s}^{-1}$ for the Cuito. Consequently, the resulting coefficient of variation is 0.93 for the Cubango, which indicates a high intraannual variation of flow and a relatively low value of 0.31 for the Cuito. Figure 5 shows the hydrographs of daily discharge at Rundu (top) and Dirico (bottom) and the associated EFCs. With a discharge value reaching $351 \mathrm{~m}^{3} \mathrm{~s}^{-1}$, the highest daily peak flow at Dirico was observed during a large flood event on March 27th 1963. During the same day, the peak flow at Rundu was $914 \mathrm{~m}^{3} \mathrm{~s}^{-1}\left(726 \mathrm{~m}^{3} \mathrm{~s}^{-1}\right.$ above MQ) on the falling limb, after having its local maximum of $949 \mathrm{~m}^{3} \mathrm{~s}^{-1}$ on March 24th 1963 (corresponding to the second highest peak within the analysed time series). The highest peak flow recorded for the Cubango during the investigated period was measured on April 1st 1969 with a maximum of $960 \mathrm{~m}^{3} \mathrm{~s}^{-1}$. On the same day, the observed discharge at Dirico was $256 \mathrm{~m}^{3} \mathrm{~s}^{-1}$ on a rising limb having its local maximum eight days later on the 9th of April. During the Large Flood event registered at Mukwe in February 1968, both tributaries recorded peak flows corresponding to a 2 year return interval event, with the discharge maximum slightly below the Large Flood event threshold (Fig. 5 top and bottom). Each of the two hydrographs in Fig. 5 shows that there is a much greater intraannual hydrological dynamism within the Cubango than in the Cuito River basin. The Cubango River shows a broader range between low flow periods and peak flow periods compared to the Cuito River at Dirico. Furthermore, it is shown that flood pulses and rapid discharge caused by precipitation events in the upper parts of the basin occur earlier in the lower Cubango than in the lower Cuito River basin. Reasons for this behaviour are the combined effects of groundwater contribution to base flow and wet season storage of floodwaters in the vast floodplains of the Cuito system, as well as the continuous release of subsurface water into the river during the time with no precipitation (OKACOM 2011).

The FDC for the Cubango shows alternating low base flow periods and relatively high flood flow periods as well as a high absolute difference between the minimum and the maximum discharge values (Fig. 6). This characteristic is an indicator of the predominance of surface and near-surface runoff generation processes, especially within the upper parts of the basin where most of the river discharge is generated (Tshimanga \& Hughes 2012). The steep slope of the FDC in the range of High Flows ( $>75$ th percentile) also reflects the dominance of surface and near-surface runoff generation processes resulting in rapid flow. The shape of the FDC, especially the rapid falling of the low flow limb in the Low Flow range ( $<25$ th percentile), implies that the impact of decelerated flows from subsurface storages is modest. In contrast, the FDC of the Cuito River shows relatively limited variation in flow, with lower peak flow but a higher low flow level compared to the Cubango River. The smooth shape of the FDC is caused by the low intra-annual flow variability. In general, the shape of the curve is less 

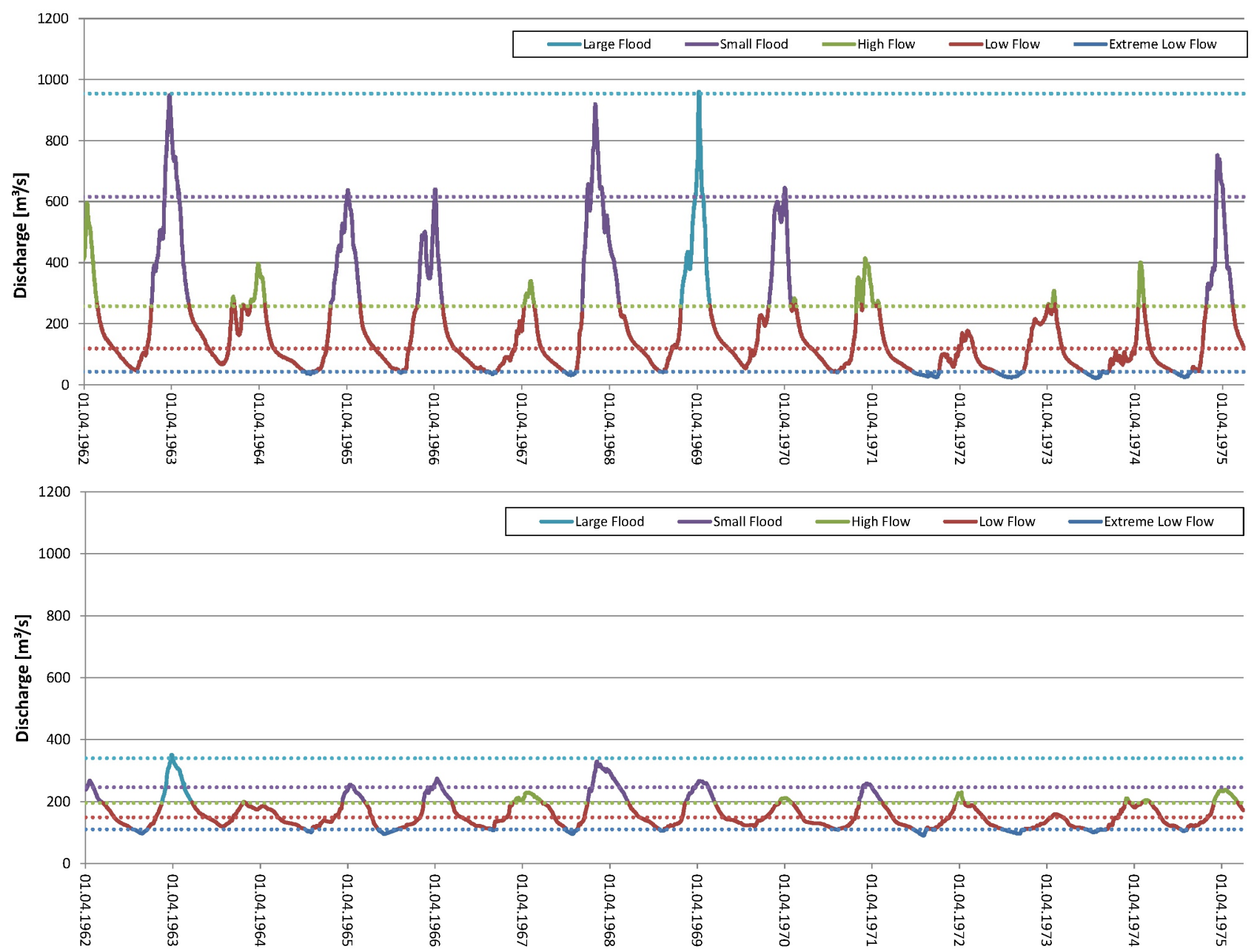

Fig. 5: Observed daily runoff of the Cubango at Rundu (top) and the Cuito river at Dirico (bottom) for the time period starting in 1962 and ending in 1975, as well as the thresholds for the EFC categories (horizontal lines) (Data: NIWR, GRDC).

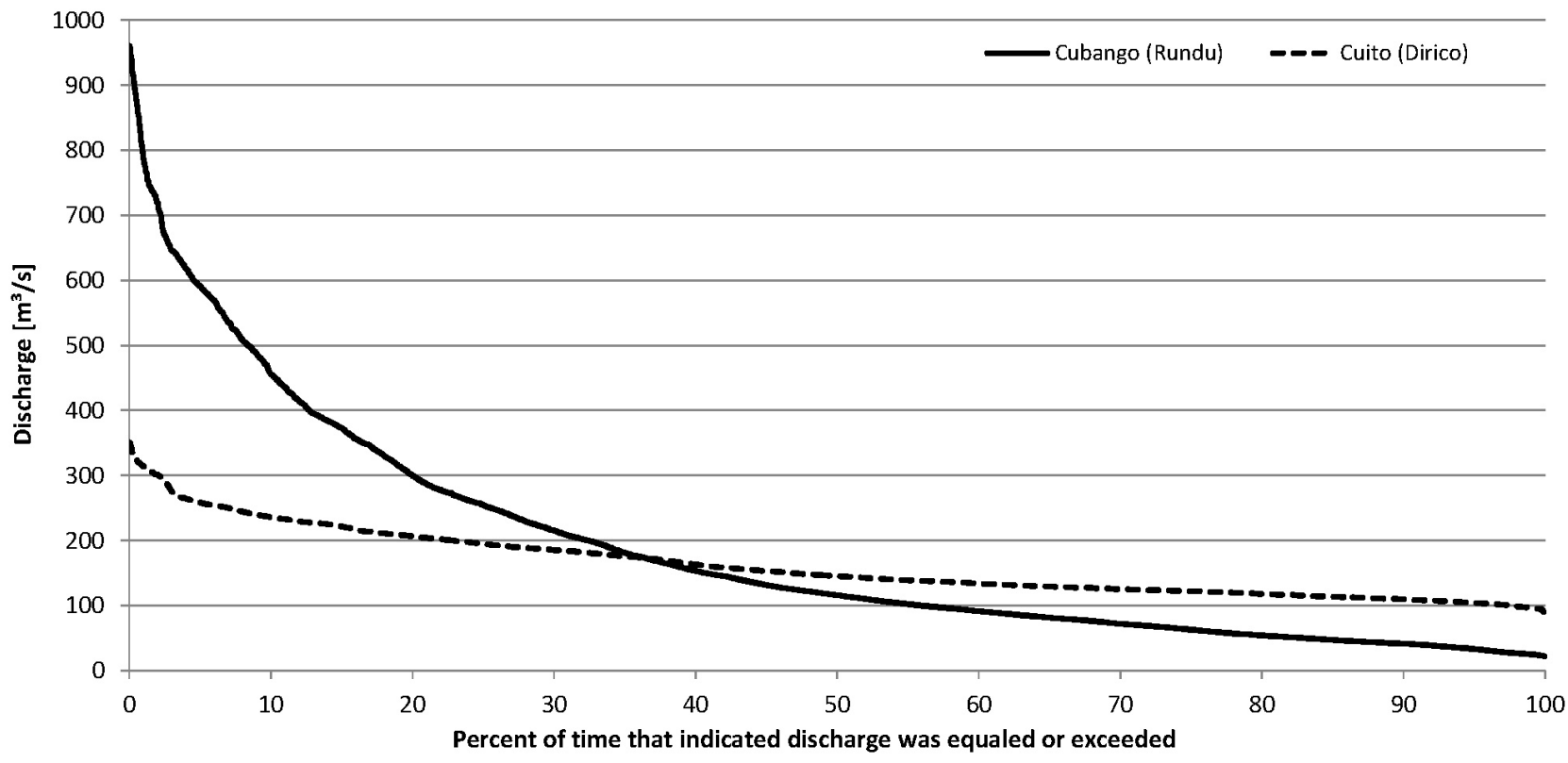

Fig. 6: Flow duration curves of daily runoff for the Cubango (at the hydrometric station of Rundu) and the Cuito (hydrometric station Dirico) (1962 - 1975) (Data: GRDC (Rundu), NIWR (Cuito)). 


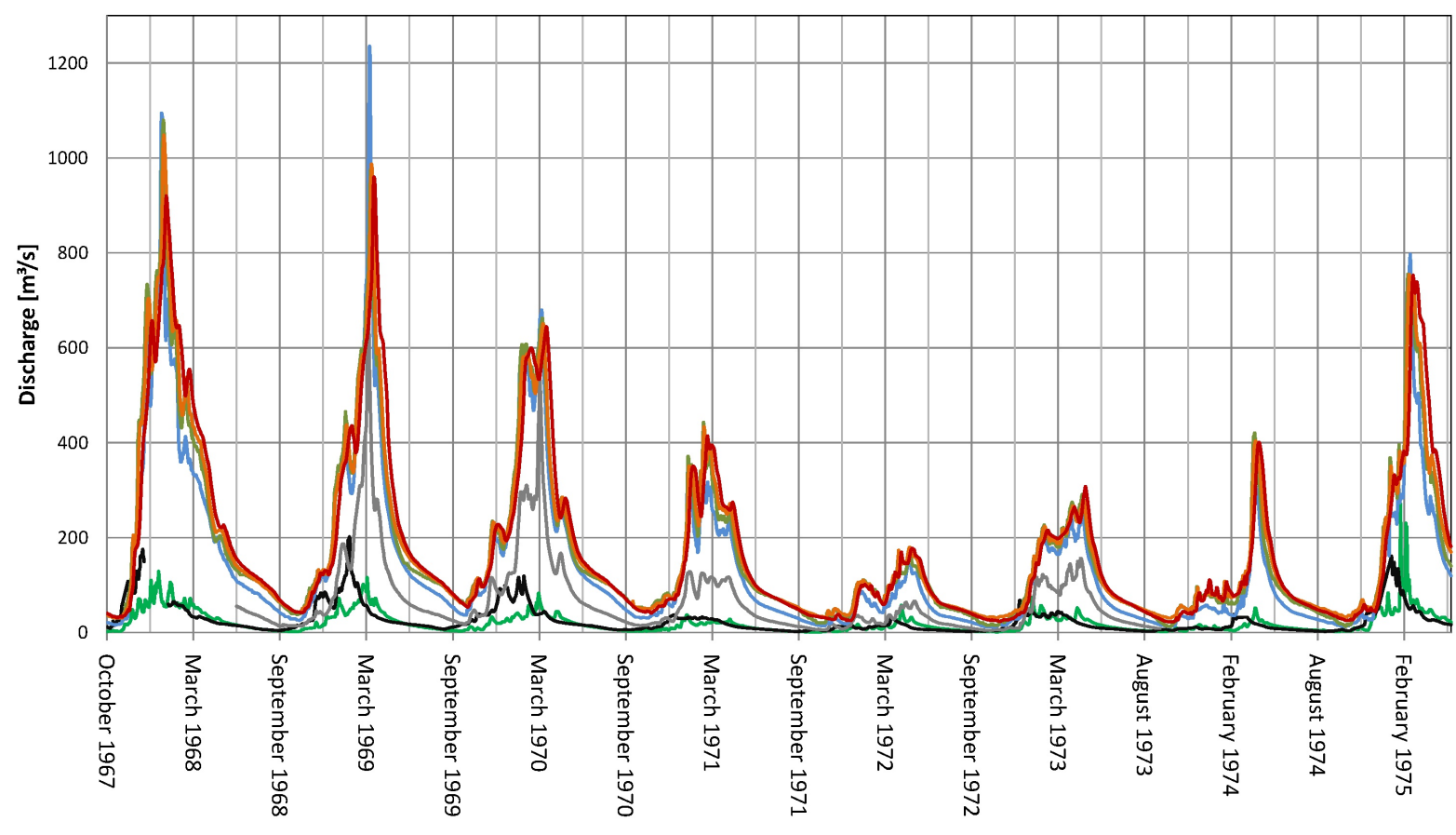

- Chinhama - Cutato - Mumba - Caiundo - Muccundi —Foz do Cuatir — Rundu

Fig. 7: Upstream - downstream flow characteristics within the Cubango tributary. The left station within the legend is the most upstream station of the Cubango tributary (Chinhama) and the station on the right is the most downstream station (Rundu) (Data: GRDC, NIWR).

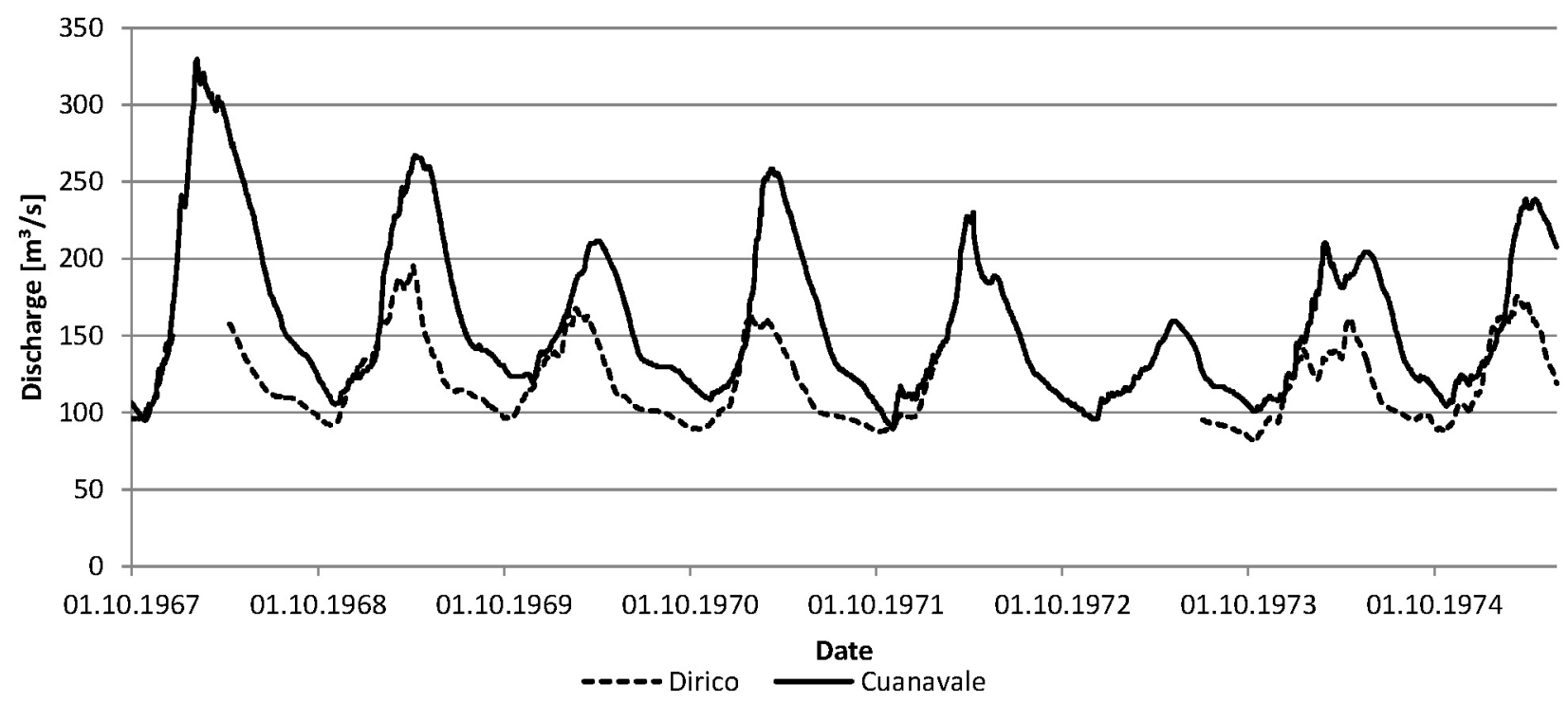

Fig. 8: Upstream - downstream flow characteristics within the Cuito tributary. The station at the Cuito in Cuito Cuanavale (here named Cuanavale) covers the headwater area including the Cuito and the Cuanavale river catchments while the downstream station of Dirico covers the complete Cuito catchment (Data: NIWR). 
Table 5. Long term mean monthly runoff, monthly coefficient of variation (CV), and the standard deviation (Stdv.) of the Cubango and Cuito runoff at the hydrometric stations at Rundu and Dirico based on time series data from 1962 to 1975 (Data: GRDC, NIWR).

\begin{tabular}{|c|c|c|c|c|c|c|}
\hline \multirow[b]{2}{*}{ Month } & \multicolumn{3}{|c|}{ Dirico } & \multicolumn{3}{|c|}{ Rundu } \\
\hline & $\begin{array}{c}\text { Mean monthly } \\
\text { discharge }\left(\mathrm{m}^{3} \mathrm{~s}^{-1}\right) \\
(1962-1975)\end{array}$ & $C V$ & Stdv. & $\begin{array}{c}\text { Mean monthly } \\
\text { discharge }\left(\mathrm{m}^{3} \mathrm{~s}^{-1}\right) \\
(1962-1975)\end{array}$ & cV & Stdv. \\
\hline January & 151.75 & 0.22 & 33.96 & 221.53 & 0.69 & 152.56 \\
\hline February & 190.5 & 0.24 & 44.94 & 331.41 & 0.56 & 184.37 \\
\hline March & 222.84 & 0.21 & 46.63 & 408.08 & 0.53 & 215.93 \\
\hline April & 230.69 & 0.18 & 41.54 & 417.95 & 0.41 & 171.08 \\
\hline May & 210 & 0.13 & 27.91 & 259.83 & 0.33 & 87.04 \\
\hline June & 179.22 & 0.11 & 20.52 & 144.41 & 0.32 & 46.82 \\
\hline July & 149.18 & 0.12 & 17.22 & 107.45 & 0.34 & 36.33 \\
\hline August & 131.28 & 0.1 & 12.78 & 85.45 & 0.34 & 28.8 \\
\hline September & 120.77 & 0.09 & 10.45 & 62.32 & 0.33 & 20.69 \\
\hline October & 110.22 & 0.07 & 8.02 & 44.66 & 0.33 & 14.7 \\
\hline November & 112.63 & 0.07 & 8.01 & 53.05 & 0.41 & 21.86 \\
\hline December & 127.38 & 0.12 & 15.44 & 116.85 & 0.84 & 97.61 \\
\hline
\end{tabular}

steep than for the Cubango and the minimum discharge does not fall below $100 \mathrm{~m}^{3} \mathrm{~s}^{-1}$. This is an indication that moderate processes dominate the runoff generation rather than rapid flows. These processes are predominantly governed by physiographic settings e.g. geology, soil type, depth and permeability, as well as the vegetation and the large floodplain area within the Cuito River catchment (Castellarin et al. 2012).

The highest monthly mean discharge at Dirico of about $231 \mathrm{~m}^{3} \mathrm{~s}^{-1}$, occurs during April, and the lowest monthly mean discharge is observed during the low flow period in October, measuring about $115 \mathrm{~m}^{3} \mathrm{~s}^{-1}$ (Table 5). The Cubango also has its highest discharge in April with a discharge peaking at $418 \mathrm{~m}^{3} \mathrm{~s}^{-1}$. In general, the Cubango peak flow in April is about 1.8 times greater than the Cuito peak flow. While the discharge measured at Rundu in May is already $37 \%$ below the mean discharge in April, the discharge measured at the Cuito in Dirico is only $10 \%$ below the mean discharge in April. This confirms that flood peaks pass the station of Dirico later if compared with the Cubango River at Rundu. The lowest monthly mean discharge of the Cubango River (approximately $45 \mathrm{~m}^{3} \mathrm{~s}^{-1}$ ) is recorded during October and November. This is 2.5 times below the Cuito discharge during the same time period which confirms the significantly higher contribution of baseflow in the Cuito River basin. In total, the mean discharge of the Cuito exceeds the discharge of the Cubango for 7 months of the year (Table 5).

The mean monthly MNQ values for the given time period are approximately 150 $\mathrm{m}^{3} \mathrm{~s}-1$ for each station. The lowest discharge is observed during October and November when the MNQ for the Cubango is $40 \mathrm{~m}^{3} \mathrm{~s}^{-1}$ and $105 \mathrm{~m}^{3} \mathrm{~s}^{-1}$ for the Cuito. The highest MNQ is measured after the rainy season in the month of April with a mean MNQ of $217 \mathrm{~m}^{3} \mathrm{~s}^{-1}$ at Dirico and $324 \mathrm{~m}^{3} \mathrm{~s}^{-1}$ at Rundu. The analysis of the MHQ for both stations shows a significant difference regarding the peak flows. The mean annual MHQ for the Cubango is $246 \mathrm{~m}^{3} \mathrm{~s}^{-1}$ whereas the value for the Cuito is $73 \mathrm{~m}^{3} \mathrm{~s}^{-1}$ less $\left(173 \mathrm{~m}^{3} \mathrm{~s}^{-1}\right)$.

\section{Upstream - Downstream Analysis}

\section{Cubango River}

The analysis of the upstream-downstream relationship within the Cubango River shows an increasing mean annual discharge from the upstream (source) areas to the downstream areas, which is in agreement with the increase of the basin size. The mean annual discharge of the most northern gauging station at Chinhama is $21 \mathrm{~m}^{3} \mathrm{~s}^{-1}$. After the confluence with the Cutato near Mumba, the mean discharge of the Cubango River increases to $67 \mathrm{~m}^{3} \mathrm{~s}^{-1}$. On its downstream course southwards, the mean annual discharge continuously increases between Mumba and the gauging station at Caiundu, reaching $171 \mathrm{~m}^{3} \mathrm{~s}^{-1}$. Here, the Cubango drains a catchment area of approximately $38.755 \mathrm{~km}^{2}$, including the sub-catchments of the Cutato, Cuchi, Cacuchi, and Cuelei. Further southwards, the Cuebe River with a catchment size of approximately $11.000 \mathrm{~km}^{2}$, drains into the Cubango and the runoff volume of the Cubango reaches its peak between the stations at Muccundi $\left(219 \mathrm{~m}^{3} \mathrm{~s}^{-1}\right)$ and Foz do Cuatir $\left(227 \mathrm{~m}^{3} \mathrm{~s}^{-1}\right)$. Figure 7 presents a comparative overview of the development of the hydrograph between the upstream region near Chinhama and the downstream area at Rundu before the confluence of both tributaries. As shown in the hydrographs in Figure 7, the difference between low flow and peak flow events, which is also reflected by the standard deviation, significantly increases from upstream to downstream areas. Whereas the standard deviation of discharge is $21 \mathrm{~m}^{3} \mathrm{~s}^{-1}$ at Chinhama, it increases drastically between Mumba (84 $\left.\mathrm{m}^{3} \mathrm{~s}^{-1}\right)$, Caiundu $\left(169 \mathrm{~m}^{3} \mathrm{~s}^{-1}\right)$, and 
Muccundi $\left(177 \mathrm{~m}^{3} \mathrm{~s}^{-1}\right)$ after the inflow of the Cuchi, Cuebe, and Cuatir (from north to south) into the Cubango River system. The standard deviation of discharge at Rundu, which is located $500 \mathrm{~km}$ downstream of the hydrometric station at Caiundu, is $180 \mathrm{~m}^{3} \mathrm{~s}^{-1}$.

The analysis of the hydrographs and the MHQ events at the hydrometric station at Caiundu and Rundu show that the mean difference in long term MNQ and MHQ does not vary significantly. The highest hydrographs are observed during February and March, while the low flow period (where mean monthly discharge is below the long term annual mean discharge) lasts from May until November, peaking in October (Fig. 7). The differences within the flood hydrographs are mostly related to their timing. By evaluating the timing of annual extremes (where the hydrograph exceeds the EFC category of a High Flow minimum) of single events, which is represented by the date of the first annual 1-day maximum, a time shift of up to 27 days (16th of January 1968) was quantified between the most upstream gauging station (Chinhama) and the downstream gauging station at Rundu. However, the majority of years show a temporal shift of 14 to 16 days in the timing of annual extreme discharge events.

\section{Cuito River}

As the Cuito River basin has only two relevant gauging stations (Cuito at Cuanavale and Dirico), hydrological upstream-downstream analysis is limited to these stations. After the confluence of the Cuito and Cuanavale rivers near Cuito Cuanavale, the mean discharge is $119 \mathrm{~m}^{3} \mathrm{~s}^{-1}$. As two small tributaries (Longa, Cuiriri) contribute to the stream flow on its course to Dirico, the mean discharge increases to $162 \mathrm{~m}^{3} \mathrm{~s}^{-1}$. The standard deviation at Cuito Cuanavale is $26 \mathrm{~m}^{3} \mathrm{~s}^{-1}$, increasing up to $51 \mathrm{~m}^{3} \mathrm{~s}^{-1}$ at Dirico, which indicates a slightly higher hydrological dynamism downstream. Low flow from Dirico $\left(81 \mathrm{~m}^{3} \mathrm{~s}^{-1}\right)$ is $10 \%$ above the low flow level of the Cuito at the gauging station in Cuito Cuanavale $\left(90 \mathrm{~m}^{3} \mathrm{~s}^{-1}\right)$. Peak flow conditions vary significantly between both stations. The MHQ is $195 \mathrm{~m}^{3} \mathrm{~s}^{-1}$ in the upstream area and reaches $351 \mathrm{~m}^{3} \mathrm{~s}^{-1}$ at Dirico. The analysis of the rising limbs of the hydrographs as well as the recession periods shows that the delay through the system, predominantly caused by the flat topography and the associated meandering of the stream and vast floodplains, is up to 40 days between the two stations within

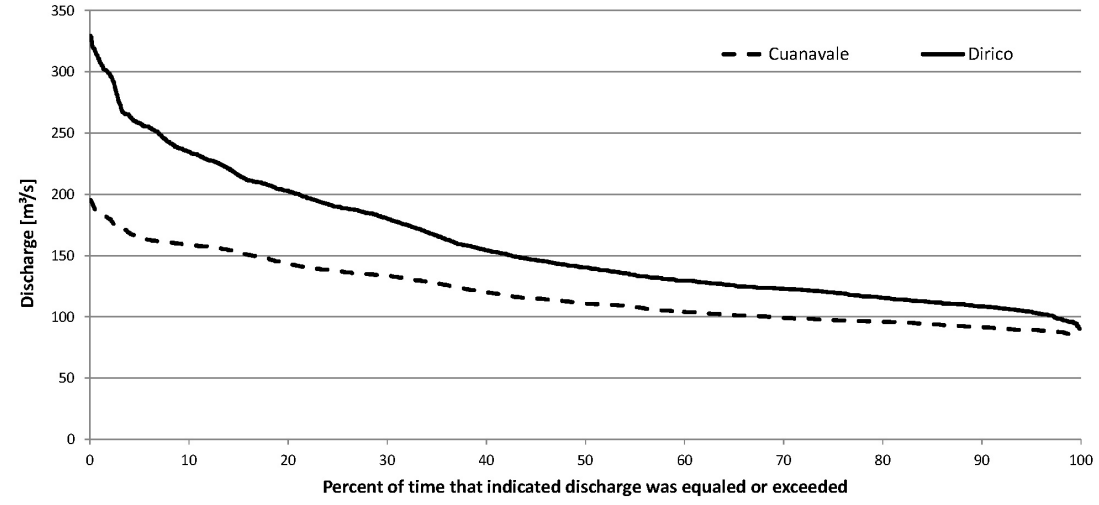

Fig. 9: Flow duration curves of daily runoff at Dirico and Cuito Cuanavale (here named Cuanavale) (Data: NIWR).

the investigated time period (Fig. 8).

The comparison of the shapes of the FDCs in Figure 9 shows a limited seasonal variation in the flow of the Cuito River system upstream of Cuito Cuanavale. The slight slope of the curve indicates a high proportion of base flow contributing to river discharge throughout the year in the upstream areas of the Cuito River catchment. Due to the physiographic characteristics within the Cuito basin discussed above, only a few high flow events contribute to discharge at the hydrometric station near Dirico (Hughes et al. 2011). The area defined between the two FDCs indicates the hydrological impact and characteristics of the Longa tributary $\left(12.900 \mathrm{~km}^{2}\right)$ draining into the Cuito north of Nankova, between Cuito Cuanavale and Dirico. It can be assumed that the inflow of this tributary especially affects and contributes to the high flow (range $>90$ th percentile) of the discharge which is later measured at Dirico, and causes high flow pulses.

\section{Conclusion and Outlook}

The aim of this paper is the hydrological assessment and analysis of the upper Okavango River basin and its main tributaries. The assessment was carried out by the analysis of hydrometeorological time series, especially precipitation and discharge. The results indicate a high spatial and temporal variation of both rainfall and discharge. It could be shown that the majority of the runoff is generated within the headwater catchments of the Cubango and Cuito River systems during the wet season. Both rivers contribute almost the same amount of mean annual discharge to the confluence downstream.

The statistical analysis of the hydrographs shows high variable flow amplitudes in the Cubango River, with a high monthly and inter-annual difference in low flow and flood flow conditions. With a significant lower frequency of high flood events and less absolute amplitude between low flow and high flow conditions, the Cuito River flow pattern appears to be smoother than that of the Cubango. The assessment also revealed that the Cubango River can deliver a discharge volume four times higher than the Cuito during flood events. In turn, the Cuito low flow discharge volume appears higher compared to the Cubango River which indicates baseflow driven runoff generation.

Inner-basin assessments have shown that almost all discharge in the Cubango is generated by quick flow generation in the headwaters of the Angolan highlands upstream of Caiundu, and no significant runoff contribution is observed from the basin area between Caiundu and Rundu. Upstream of Caiundu, the analysis has shown that tributaries contribute discharge according to their catchment size and the precipitation input received. Within the Cuito catchment, inner-basin assessments have shown that low flow periods and peak flow events occur both up and downstream, but vary in their level of magnitude. Here, only two stations had satisfying time series records, but the analysis of these records indicated that downstream of the headwaters north of Cuito Cuanavale and the system outlet close to Dirico, runoff is generated within the system and contributed to by the tributaries of the Longa River basin. Nevertheless, a delay of flood pulses in the system can be quantified by up to 40 days from the headwaters to the system outlet.

The analysed time series were compiled and pre-processed to provide quality 
checked input data for the hydrological modelling applying the $\mathrm{J} 2000$ and $\mathrm{J} 2000 \mathrm{-g}$ models of the Integrated Land Management System (ILMS) software toolset (Kralisch et al. 2012). The climate data will then be used as forcing data for the modelling of several sub-catchments in order to support better understanding and insight of the spatio-temporal pattern of runoff generation and storage dynamics. The geodatasets will be used to delineate Hydrological Response Units (HRUs) (Flügel 1995) as distributed model entities in the model exercises. The process oriented modelling approach will be a prerequisite for the analysis of future "what-if?" scenarios.

\section{Acknowledgments}

The authors would like to thank the German Federal Ministry for Education and Research (BMBF) for financial support (Project contract no. 01LL0912J). Acknowledgement is also given to the Angolan project partners and supporters (i) National Institute of Water Resources (NIWR), (ii) Ministry of Energy and Water in Luanda, (iii) the Provincial NIWR office in Menongue, and (iv) the National Institute of Meteorology and Geophysics (INAMET) for providing hydro-meteorological data, technical and scientific support. The authors would like to thank the Namibian supporters (i) Ministry of Water, Agriculture and Forestry in Namibia and (ii) the Mashare Agricultural Development Institute (MADI) for providing rainfall data. Also all TFO partners contributing to this study are gratefully acknowledged. Also we would like to thank the GRDC for providing discharge data.

\section{References}

Andersson, L., Gumbricht, T., Hughes, D., Kniveton, D., Ringrose, S., Savenije, H., Todd, M., Wilk, J., Wolski, P. (2003): Water flow dynamics in the Okavango River Basin and the Delta - a prerequisite for the ecosystems of the Delta. - Physics and Chemistry of the Earth 28: 1165-1172. CrossRef

Arino, O., Ramos, P., Jose, J., Kalogirou, V., Bontemps, S., Defourny, O., Van Bogaert, E. (2012): Global Land Cover Map for 2009 (GlobCover2009). European Space Agency (ESA) \& Universite catholique de Louvain (UCL), doi: 1. 1594/PANGAEA.787668

Bareslavski, E. (1997): Geohydrology,
Geology, and Soils of the Cubango River Basin (Angolan Sector). Specialist Report prepared by Etel Bereslawski. Luanda, Angola, December 1997.

Bauer, P., Held, R., Zimmermann, S., Linn, F., Kinzelbach, W. (2006): Coupled flow and salinity transport modelling in semiarid environments: the Shashe River Valley, Botswana. - Journal of Hydrology 316: 163-183. CrossRef

Butchart-Kuhlmann, D. (2012): Assessing Spatial Data Quality for Application Development within OBIS (Okavango River Basin Information System). MScThesis, Friedrich Schiller University, Jena, Germany

Castellarin, A., Botter, G., Hughes, D.A., Liu, S., Ouarda, T.B.M.J., Parajka, J., Post, D.A., Sivapalan, M., Spence, C., Viglione, A., Vogel, R.M. (2013): Prediction of flow duration curves in ungauged basins. - In: Blöschl, G., Sivapalan, M., Wagener, T., Viglione, A., Sa Venije, H. [Eds.]: Runoff Prediction in Ungauged Basins: Synthesis across Processes, Places and Scales. 135-162. Cambridge: Cambridge University Press

Dijkshoorn, J.A., van Engelen V.W.P., Huting J.R.M. (2008): Soil and landform properties for LADA partner countries (Argentina, China, Cuba, Senegal and Gambia, South Africa and Tunisia), ISRIC- World Soil Information, Wageningen.

Dincer, T., Child, S., Khupe, B. (1987): A simple mathematical model of a complex hydrological system: Okavango Swamp, Botswana. - Journal of Hydrology 93: 41-65.

FAO (Food and Agricultural Organization of the United Nations) (2001): FAOCLIM 2.0 A World-Wide Agroclimatic Database. Food and Agriculture Organization of the United Nations: Rome, Italy.

Flügel, W.-A. (1995): Delineating Hydrological Response Units (HRU's) by GIS analysis for regional hydrological modelling using PRMS/MMS in the drainage basin of the River Bröl, Germany. - Hydrological Processes 9: 423-436. CrossRef

Folwell, S., Farqhuarson, F. (2006): The impacts of climate change on water resources in the Okavango basin. In: Demuth, S. et al. [Eds.] Climate variability and change: hydrological impacts, P. 382-387. IAHS Publication 308. Oxfordshire: IAHS.

Friedl, M, Sulla-Menashe, D., Tan, B., Schneider, A., Ramankutty, N., Sibley, A., Huang, X. (2010): MODIS Collection 5 global land cover: Algorithm refinements and characterization of new Datasets. - Remote Sensing of Environment 114(1): 168-182. CrossRef Gao, Y., Vogel, R.M., Kroll, C.N. Poff, N.L., Olden, J.D. (2009): Development of representative indicators of hydrologic alteration. - Journal of Hydrology 374 : 136-147. CrossRef

Gieske, A. (1997): Modelling outflow from the Jao/Boro river system in the Okavango delta, Botswana. - Journal of Hydrology 193: 214-239.

GRDC (2013): Runoff Data for the Okavango River catchment- The Global Runoff Data Centre, 56068 Koblenz, Germany

Gumbricht, T., McCarthy, T.S., Merry, C.L. (2001): The topography of the Okavango Delta, Botswana, and its tectonic and sedimentological implications. - South African Journal of Geology 104: 243-264. CrossRef

Gumbricht, T., McCarthy, T. S., Bauer, P. (2005): The microtopography of the wetlands of the Okavango Delta, Botswana. - Earth Surface Processes and Landforms 30: 27-39. CrossRef

Haddon, I.G. (2005): The sub-Kalahari geology and tectonic evolution of the Kalahari Basin, southern Africa. Unpublished $\mathrm{PhD}$ thesis, University of the Witwatersrand, South Africa, 343pp.

Haddon, I.G., McCarthy, T.S. (2005): The Mesozoic-Cenozoic interior sag basins of Central Africa: The Late-CretaceousCenozoic Kalahari and Okavango basins. - Journal of African Earth Sciences 43: 316-333. CrossRef

Hijmans, R.J., Cameron, S.E., Parra, J.L., Jones, P.G., Jarvis, A. (2005): Very high resolution interpolated climate surfaces for global land areas. - International Journal of Climatology 25: 1965-1978. CrossRef

Hudson, D.A., Jones, R.G. (2002): Simulations of present day and future climate over southern Africa using HadAM3H. Hadley Centre Technical Note 38, Hadley Centre for Climate Prediction and Research, Met. Office, Bracknell, UK.

Hughes, D.A. (2004): Incorporating groundwater recharge and discharge functions into an existing monthly rainfall-runoff model. - Hydrological Sciences Journal 49: 297-311. CrossRef Hughes, D.A., Kingston, D.G., Todd, M.C. (2011): Uncertainty in water resources availability in the Okavango River Basin as a result of climate change. Hydrology and Earth System Sciences 15: 931-941. CrossRef

Hughes, D.A., Andersson, L., Wilk, J., Savenije, H.H.G. (2006): Regional calibration of the Pitman model for the Okavango River. - Journal of Hydrology 331: 30-42. CrossRef

Hughes, D.A., Forsyth, D. A. (2006): A generic database and spatial interface for the application of hydrological and water resource models. - Computers \& Geosciences $32 \quad$ (9): 1389-1402. CrossRef

Hughes, R.H., Hughes, J.S. (1992): A Directory of African Wetlands. International Union for the Conservation 
of Nature and Natural Resources (IUCN). Gland, Switzerland.

Hulme, M., Doherty, R., Ngara, T., New, M., Lister, M. (2001): African climate change 1900 - 2100. - Climate Research 19 145-168. CrossRef

Hutchison, I.P.G., Midgley, D.C. (1973): A mathematical model to aid management of outflow from the Okavango swamp, Botswana. - Journal of Hydrology 19: 93-112. CrossRef

Kgathi, D.L., Kniveton, D., Ringrose, S. Turton, A.R., Vanderpost, C.H.M., Lundqvist, J., Seely, M. (2006): The Okavango; a river supporting its people, environment and economic development. - Journal of Hydrology 331: 3-17. CrossRef

Kralisch, S., Böhm, B., Böhm, C., Busch, C., Fink, M., Fischer, C., Schwartze, C., Selsam, P., Zander, F., and Flügel, W.-A. (2012): ILMS - a Software Platform for Integrated Environmental Management. - In: Seppelt, R., Voinov, A.A., Lange, S., and Bankamp, D. (Eds.): iEMSs Proceedings, 2012 International Congress on Environmental Modelling and Software Managing Resources of a Limited Planet, Sixth Biennial Meeting, Leipzig,

Germany, (http://www.iemss.org/society/index.php/i emss-2012-proceedings)

Mahon, T.A. (1987): Hydrological Characteristics of Selected Rivers of the World. Technical Documents in Hydrology. Paris: UNESCO.

Manley, R.E. (1997): Hydrological modelling of the Okavango Delta system in Botswana, specialist report in: Feasibility study on the Okavango River to Grootfontein link of the Eastern National Water Carrier, vol. 4, Department of Water Affairs, Republic of Namibia.

Marques, R. (1997): Climate, hydrology and water resources (Angolan sector). Okavango River Basin Preparatory Assessment Study, Draft Translation, OKACOM.

Mazvimavi, D., Wolski, P. (2006): Longterm variations of annual flows of the Okavango and Zambezi rivers. - Physics and Chemistry of the Earth 31: 944-951. CrossRef

Mendelsohn, J., el Obeid, S. (2004): Okavango River. The Flow of a Lifeline. Struik Publishers, Cape Town, South Africa.

Milzow, C., Kgotlhang, L., Bauer-Gottwein, P., Meier, P., Kinzelbach, W. (2009): Regional review: the hydrology of the Okavango Delta, Botswana-processes, data and modelling. - Hydrogeology Journal 17: 1297-1328. CrossRef

NASA Land Processes Distributed Active Archive Center (LP DAAC) (2010): MODIS MCD12Q1 version5.1. USGS/Earth Resource Observation and Service (EROS) Center, Sioux Falls, South Dakota.
Norwegian Water Resources and Energy Directorate (2004): Quality check historical data in Angola. Status by 2004. Nivel de Agua (water level), Medicao de Caldal (discharge measurements), Curva de vacao (rating curves), Caudais medios diarios (daily mean water flow). Oslo, December 2004.

OKACOM (The Permanent Okavango River Basin Water Commission) (1998): Okavango River Basin Transboundary Diagnostic Analysis (TDA). Maun, Botswana: OKACOM, May 1998.

OKACOM (The Permanent Okavango River Basin Water Commission) (2011): Cubango-Okavango River Basin Transboundary Diagnostic Analysis (TDA). Maun, Botswana: OKACOM 2011.

Pitman, W.V. (1973): A mathematical model for generating river flows from meteorological data in South Africa. Report No. 2/73, Hydrological Research Unit, University of the Witwatersrand Johannesburg, South Africa.

Richter, B.D., Baumgartner, J.V., Powell, J., Braun, D.P. (1996): A Method for assessing Hydrologic Alteration within Ecosystems. - Conservation Biology 10(4): 1163-1174. CrossRef

Richter, B.D., Thomas, G.A. (2007): Restoring Environmental Flows by Modifying Dam Operations. - Ecology and Society 12(1): 12p. URL: URL: http://www.ecologyandsociety.org/vol12/i ss1/art12/

Ringrose, S., Huntsman-Mapila, $P$. Downey, W., Coetzee, S., Fey, M., Vanderpost, C., Vink, B., Kemosidile, T., Kolokose, D. (2008): Diagenesis in Okavango fan and adjacent dune deposits with implications for the record of palaeo-environmental change in Makgadikgadi-Okavango-Zambezi basin, northern Botswana. Geomorphology 101: 544-557. CrossRef

Servicio Geologico de Angola (1988): Map of Mineral Resources of Angola - Carta dos Recursos Minerals elaborada [Ed.]: Manual, J., Silva, M.F.S., Khorochev, P.I., Luanda, Angola

The Nature Conservancy (2009): Indicators of Hydrologic Alteration Version 7.1. User's Manual.

Tshimanga R.M., Hughes D.A. (2012): Climate change and impacts on the hydrology of the Congo Basin: The case of the northern sub-basins of the Oubangui and Sangha Rivers. - Physics and Chemistry of the Earth 50-52: 72-83.

USGS (United States Geological Survey) (2003): Shuttle Radar Topography Mission (SRTM). Fact Sheet 071-03. U.S. Geological Survey, Reston, $2 p$.

Verissimo, L. (2009): GIS Database for the Environment Protection and Sustainable Management of the Okavango River Basin Project EPSMO - URL: http://www.

http://epsmo.iwlearn.org/publications/file s/environmental-analyses [accessed on 2013-07-10]

Viola, F., Noto, L.V., Cannarozzo, M., La Loggia, G. (2011): Regional flow duration curves for ungauged sites in Sicily. - Hydrology and Earth System Sciences 15: 323-331. CrossRef

Wilk, J., Kniveton, D., Andersson, L., Layberry, R., Todd, M.C., Hughes, D., Ringrose, S., Vanderpost, C. (2006): Estimating rainfall and water balance over the Okavango River Basin for hydrological applications. - Journal of Hydrology 331: 18-29. CrossRef

Wolski, P., Murray-Hudson, M. (2006): Flooding dynamics in a large lowgradient alluvial fan, the Okavango Delta, Botswana, from analysis and interpretation of a 30-year hydrometric record. - Hydrology and Earth System Sciences 10: 127-137. CrossRef

Wu, H., Soh, L.K., Samal, A., Hong, T., Marx, D., Chen, X. (2009): UpstreamDownstream Relationships in Terms of Annual Streamflow Discharges and Drought Events in Nebraska. - Journal of Water Resource and Protection 1: 299-315. CrossRef

\section{Affiliations}

Thomas Steudel* (thomas.steudel@unijena.de), Hendrik Göhmann

(hendrik.goehmann@uni-jena.de),

Wolfgang-Albert Flügel (c5wafl@uni-

jena.de)

Department of Geoinformatics,

Hydrology and Modelling

Friedrich-Schiller-University Jena

Löbdergraben 32

07743 Jena, GERMANY

Jörg Helmschrot (joerg.helmschrot@unihamburg.de)

Biodiversity, Evolution and Ecology of Plants, Biocentre Klein Flottbek and

Botanical Garden ,University of Hamburg

Ohnhorststr. 18

22609 Hamburg, GERMANY

*Corresponding authors 
